\title{
RULE BASED MODELING UNTUK IDENTIFIKASI DAERAH POTENSI BANJIR
}

\author{
Rina Fiati \\ Fakultas Teknik, Program Studi Teknik Informatika \\ Universitas Muria Kudus \\ Email: rfiati003@yahoo.com \\ Anastasya Latubessy \\ Fakultas Teknik, Program Studi Teknik Informatika \\ Universitas Muria Kudus \\ Email: anastasyalatubessy@gmail.com
}

\begin{abstract}
ABSTRAK
Banjir merupakan bencana tahunan yang marak terjadi di wilayah Indonesia saat ini. Upaya pencegahan tanpa memperhatikan kemungkinan daerah yang berpotensi banjir dirasa tidak optimal. Identifikasi awal derah berpotensi banjir perlu dilakukan agar dapat digunanakn sebagai titik-titik prioritas daerah pencegahan banjir. Identifikasi daerah banjir dapat dilakukan dengan memanfaatkan perkembangan teknologi Sistem Pakar. Dengan memanfaatkan Sistem Cerdas untuk mengembangkan model identifikasi daerah potensi banjir, dapat menghasilkan sebuah sistem untuk identifikasi daerah potensi banjir. Langkah awal penting yang harus dilakukan adalah membangun Rule Base Modeling, dengan metode production rule. Parameter atau tolok ukur ditentukan berdasarkan luas genangan $(\mathrm{km} 2$, hektar), kedalaman atau ketinggian air banjir (meter), kecepatan aliran (meter/detik, km/jam), material yang dihanyutkan aliran banjir (batu, bongkahan, pohon, dan benda keras lainnya), tingkat kepekatan air atau tebal endapan lumpur (meter, centimeter), dan lamanya waktu genangan (jam, hari, bulan). Penelitian ini menghasilkan rule based modeling dengan enam parameter utama untuk mengidentifikasi daerah potensi banjir.
\end{abstract}

Kata kunci: model, pakar, paramater, banjir

\section{ABSTRACT}

Today, flood becomes yearly disaster in Indonesia. An effort without keeping care to the potential flooded areas, it doesn't mean optimal effort. Identifying to the potential flooded areas is important to determine the potential avoiding flooded areas. Identification to the potential flooded areas can be done by using the developing technology of Expert System. By using the technology of Expert System to develop an identifying model to the potential flooded areas, it can produce a system to identify the potential flooded areas. A primary step that must be done first is to develop Rule Base Modeling using production rule method. A parameter used in here is determined based on the large flooded areas (Km2, hectare), depth (meter), rapidity (meter/second, $\mathrm{km} / \mathrm{hour}$ ), flooded material (building, trees, bridges, ect.), the rate of sticky muddy (meter, centimeter), and the duration of the flood (hour, day, month). This research brings about a rule based modeling with six main parameters in identifying the potential flooded areas.

Keywords: modeling, expert, parameter, floods

\section{PENDAHULUAN}

Secara naluriah manusia memiliki kecenderungan untuk selalu memahami lingkungan. Manusia dan lingkungan memiliki ikatan keterjalinan yang dekat satu sama lain. Ikatan yang terjalin antara manusia dan lingkungan inilah yang kemudian membuat manusia melakukan upaya-upaya untuk mengurangi dampak pemanasan global. Akan tetapi, hingga saat ini dampak dari pemanasan global di rasakan masih terjadi. Pemanasan global yang terjadi dewasa ini diduga akibat kecerobohan manusia dalam mengelola lingkungan alam.

Beberapa di antara kecerobohan yang telah di lakukan oleh manusia adalah pencemaran udara oleh asap pabrik industri dan penggundulan hutan tanpa melakukan penanaman kembali, bumi terancam bencana dalam bentuk baru akibat adanya perubahan iklim atau yang lebih sering kita dengar dengan istilah pemanasan global. Di Indonesia banyak mengalami perubahan iklim yang memberikan dampak pada berbagai sektor kehidupan. Hal ini juga dampak dari pola hujan di Indonesia sangat bervariasi. 
Akhir-akhir ini kejadian El-Nino semakin sering dan intensitas cenderung menguat hingga terjadi kejadian cuaca dan iklim ekstrim. Kejadian ini sangat berkaitan dengan adanya pemanasan global.

Banjir merupakan bencana di Indonesia, Parameter atau tolok ukur dapat ditentukan berdasarkan luas genangan (km2, hektar), kedalaman atau ketinggian air banjir (meter), kecepatan aliran (meter/detik, $\mathrm{km} / \mathrm{jam}$ ), material yang di hanyutkan aliran banjir (batu,bongkahan, pohon, dan benda keras lainnya), tingkat kepekatan air atau tebal endapan lumpur (meter, centimeter), dan lamanya waktu genangan (jam, hari, bulan). Dengan pengetahuan sistem pakar (expert system) di terapkan dalam pemodelan untuk identifikasi daerah-daerah potensi banjir. Salah satu metode sistem pakar yang di gunakan yaitu production rule. Data identifikasi yang di peroleh akan di gunakan untuk memetakan daerah potensi banjir dengan menggunakan teknologi sistem informasi geografis (Geographical Information System/GIS). Pada penelitian ini lebih di fokuskan pada daerah-daerah di Kabupaten Kudus.

Ada beberapa definisi tentang sistem pakar yaitu sistem yang berusaha mengapdosi pengetahuan manusia ke komputer, agar komputer dapat menyelesaikan masalah seperti yang biasa dilakukan oleh para ahli. Sistem pakar dapat di tampilkan dengan dua lingkungan : lingkungan pengembangan dan lingkungan konsultasi (runtime). Lingkungan pengembangan di gunakan oleh pengembang sistem pakar untuk membangun komponen dan memasukkan pengetahuan ke dalam basis pengetahuan. Lingkungan konsultasi di gunakan oleh non pakar untuk memperoleh pengetahuan dan nasihat pakar. Lingkungan ini dapat di pisahkan setelah sistem lengkap. Ada tiga komponen utama yang tampak secara virtual di setiap sistem pakar adalah basis pengetahuan, mesin inferensi, dan antarmuka pengguna [1].

Beberapa penelitian terkait seperti yang di lakukan oleh, Zubaidah,dkk pada tahun 2005 yang melakukan Analisa terhadap daerah potensi banjir di Pulau Sumatra, Jawa dan Kalimantan menggunakan Citra AVHRR/NOAA-16. Tujuan penelitian ini adalah melakukan analisis daerah potensi banjir menggunakan data satelit penginderaan jauh yang memiliki resolusi temporal tinggi, pada penelitian ini digunakan citra NOAA 16 AVHRR kanal 1 (sinar tampak) dan kanal 4 (inframerah). Lokasi penelitian mencakup wilayah Indonesia bagian barat yaitu Pulau Sumatera, Jawa dan Kalimantan. Hasil analisis daerah genangan menunjukkan bahwa lokasi genangan terdapat di 26 kabupaten di seluruh P. Jawa, 42 kabupaten terdapat di pulau Sumatera dan 21 lokasi genangan di seluruh Kalimantan. Hasil integrasi dengan data estimasi awan berpeluang hujan lebat harian menunjukkan daerah-daerah yang potensial mengalami kejadian banjir. Hasil validasi menunjukkan bahwa 71\% kejadian banjir di Pulau Sumatera, Jawa dan Kalimantan pada bulan Januari 2005 sesuai dengan hasil analisa [2].

Pemanfaatan teknologi informasi mulai digunakan untuk identifikasi daerah rawan banjir, seperti yang dilakukan oleh Indrianawati pada tahun 2009 dalam penelitiannya yang berjudul, Penyusunan Basis Data Untuk Identifikasi Daerah Rawan Banjir Dikaitkan Dengan Infrastruktur Data Spasial (Studi Kasus Propinsi Jawa Barat). Penelitian ini dilakukan untuk membangun model basis data untuk mengetahui apakah data dasar yang diperlukan ini tersedia dan dapat digunakan untuk identifikasi daerah rawan banjir[3].

Penanggulangan bencana banjir harus terstruktur mengikuti tahapan prabencana, tanggap darurat dan pasca bencana, dan sesuai paradigma baru penanggulangan bencana dari 'tanggap darurat' ke 'pengurangan resiko bencana'. Untuk itu upaya-upaya pengurangan resiko bencana harus tetap dilakukan dan selalu ditingkatkan. Salah satu upaya tersebut adalah dengan memberikan pengetahuan praktis tentang karakteristik bencana dan upaya-upaya mitigasinya kepada seluruh pemangku kepentingan (stake holder). Pernyataan tersebut dipaparkan dalam penelitian yang berjudul, Bencana banjir, pengenalan karakteristik dan kebijakan Penanggulangannya di provinsi Kalimantan Timur [4].

\section{METODOLOGI PENELITIAN}

\subsection{Metode Pendekatan}

Metode Pengembangan yang digunakan dalam penelitian ini adalah Production Rule. Dalam pendekatan ini dilakukan tahapan-tahapan untuk menganalisa kebutuhan sebagai dasar dari pengembangan rule. Berdasarkan hasil analisa, kemudian dikembangkan ke dalam rancangan decission tree dan kaidah rule.

\subsection{Metode Pengumpulan Data}

Metode pertama yang digunakan adalah library research yaitu dengan cara mempelajari bahanbahan tertulis serta mengumpulkan data-data, browsing data via internet dan masalah-masalah berkaitan. Untuk metode yang kedua adalah teknik interview dan observasi. Pada metode ini peneliti mencari dan mengumpulkan data-data yang ada relevansinya dengan judul penelitian ini pada pihak 
terkait yaitu unit Penelitian dan Instansi yang terkait. Diantanya Badan Penanggulangan Bencana Daerah (BPBD) dan BMKG. Sumber data yang digunakan dalam penelitian ini adalah indikator-indikator yang ditetapkan dari sumber data internal seperti luas genangan (km2, hektar), kedalaman atau ketinggian air banjir (meter), kecepatan aliran (meter/detik, $\mathrm{km} / \mathrm{jam}$ ), material yang di hanyutkan aliran banjir (batu,bongkahan, pohon, dan benda keras lainnya), tingkat kepekatan air atau tebal endapan lumpur (meter, centimeter), dan lamanya waktu genangan (jam, hari, bulan).

\subsection{Analisa Kebutuhan}

Dalam membuat pemodelan sistem dibutuhkan data, diantaranya Data Daerah rawan banjir dan Data Parameter identifikasi daerah rawan banjir. Berdasarkan data-data tersebut, diharapkan dapat menghasilkan sebuah pemodelan keputusan yang dapat digunakan untuk mengidentifikasi daerah rawan banjir berdasarkan enam parameter yang telah ditentukan. Gambar 1 menunjukan peta bencana banjir dan tanah longsor 2014 di Kabupaten Kudus, Jawa Tengah.

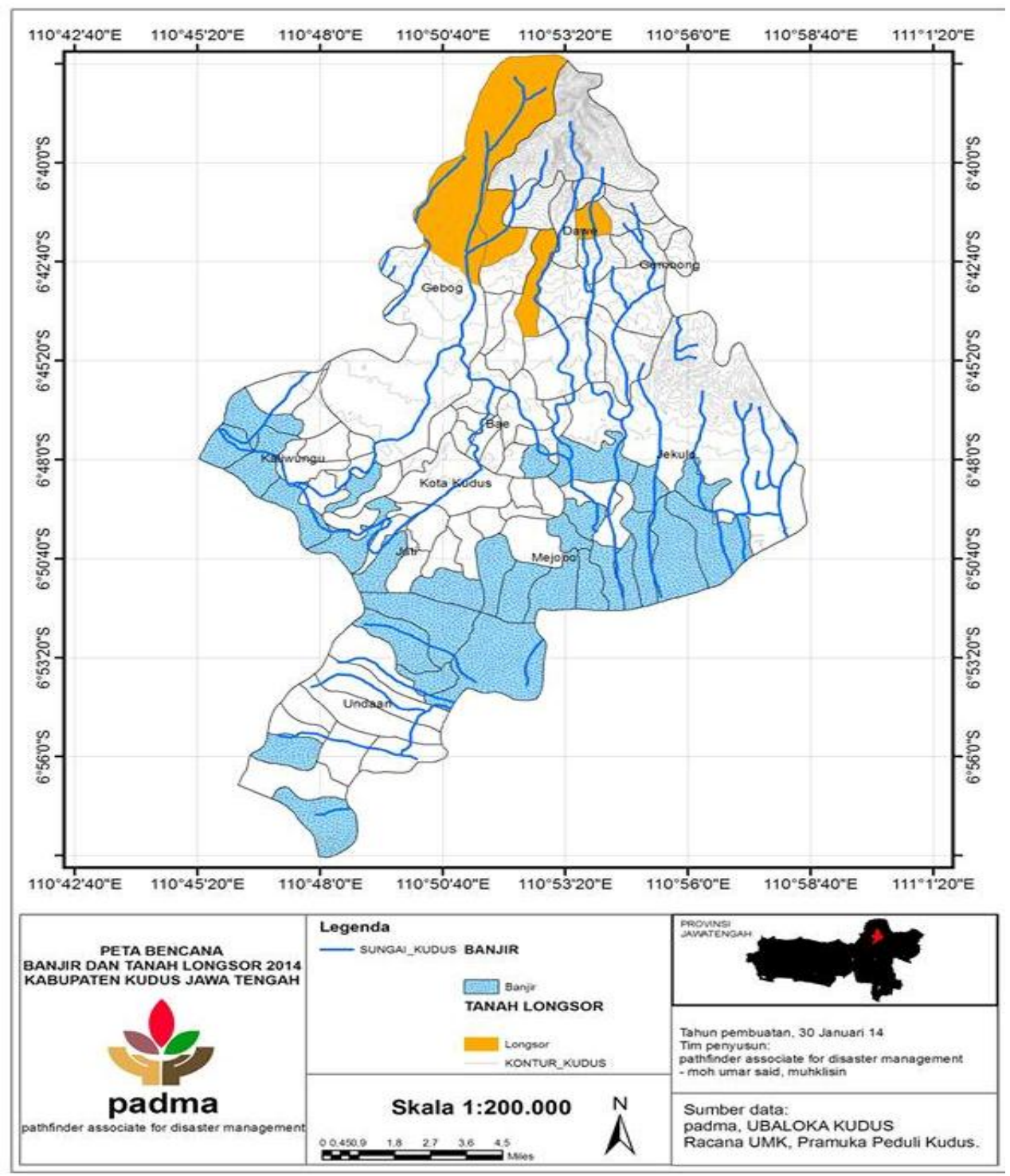

Gambar 1. Peta Banjir Kudus

Daerah yang berwarna kuning merupakan daerah longsor, sementara daerah yang berwarna biru pada peta merupakan daerah banjir. Pada Gambar 1 dilihat bahwa daerah yang berwarna biru yang merupakan daerah banjir Kudus, memiliki persebaran yang cukup tinggi. 


\section{Tabel 1. Laporan Kejadian Bencana Banjir BPSDA Seluna Tahun 2014(Sumber : BPBD Kudus)}

\begin{tabular}{|c|c|c|c|c|c|c|c|c|c|}
\hline No. & Nama Sungai & $\begin{array}{c}\text { HARI/TANGGAL } \\
\text { /JAM }\end{array}$ & & Lokasi & Sebab / Akibat / Kejadian & $\begin{array}{l}\text { Daerah } \\
\text { Genangan }\end{array}$ & $\begin{array}{l}\text { Luas / } \\
\text { Pjg } \\
\text { Genangan }\end{array}$ & $\begin{array}{l}\text { Tinggi } \\
\text { (m) } \\
\text { Genangan }\end{array}$ & $\begin{array}{l}\text { Lama } \\
\text { (jam) }\end{array}$ \\
\hline 1 & 2 & 3 & & 4 & 5 & 6 & 7 & 8 & 9 \\
\hline \multirow[t]{3}{*}{1} & Simo & Rabu & Ds. & Widorokandang & Luapan sungai Simo \& curah hujan tinggi & rumah & $150 \mathrm{kk}$ & $1-1,5$ & 3 hari \\
\hline & & 01-Jan-14 & Kec. & Pati & & jln desa & $600 \mathrm{~m}$ & & \\
\hline & & 14.00 wib & Kab. & Pati & & sawah & $25 \mathrm{Ha}$ & & \\
\hline \multirow[t]{3}{*}{2} & Sungai Bendo & Rabu & Ds. & Tahunan & Curah Hujan tinggi & rumah & $100 \mathrm{kk}$ & $0,5-1$ & 1 hari \\
\hline & & 01-Jan-14 & Kec. & Tahunan & luapan sungai Bendo & & & & \\
\hline & & 03.00 wib & Kab. & Jepara & & & & & \\
\hline \multirow[t]{3}{*}{3} & Sungai Sangon & Rabu & Ds. & Sumberrejo & Tanggul sungai sangon jebol & rumah & $130 \mathrm{kk}$ & & \\
\hline & & 01-Jan-14 & Kec. & Donorejo & $\mathrm{p}=2 \mathrm{~m}$. & & & & \\
\hline & & 05.30 wib & Kab. & Jepara & & & & & \\
\hline \multirow[t]{3}{*}{4} & Sal Irigasi & Kamis & Ds. & Batangan & Sal Irigasi BWKa.05 (DI.Widodaren) & & & & \\
\hline & BWKa.05 & 01/09/2014 & Kec. & Batangan & pintu rusak, menggenangi Jln raya Batangan & jln & $300 \mathrm{~m}$ & $0,3-0,5$ & \\
\hline & & 18.00 wib & Kab. & Pati & & & & & \\
\hline \multirow[t]{3}{*}{5} & Sungai Pasokan & kamis & Ds. & Puncel & curah hujan tinggi & rumah & $400 \mathrm{kk}$ & $0,3-0,5$ & 3 hari \\
\hline & & $16-1-2014$ & Kec. & Dukuhseti & mushola, mi dan sd, TPI (tempat Pelelangan ikan) & & & & \\
\hline & & 10.00 wib & Kab. & Pati & \& tambak seluas $25 \mathrm{Ha}$. Terrendam & & & & \\
\hline \multirow[t]{3}{*}{6} & Sungai Simo & Minggu & Ds. & Widorokandang & curah hujan tinggi \& luapan s. simo & rumah & $150 \mathrm{kk}$ & $1-2$ & 4 hari \\
\hline & & $19-1-2014$ & Kec. & Pati & mengancam jalur pantura Pati-Rembang & & & & \\
\hline & & 24.00 wib & Kab. & Pati & sawah tergenang: padi umur 40 hari & sawah & $200 \mathrm{Ha}$ & & \\
\hline \multirow[t]{3}{*}{7} & Sungai Pasokan & Minggu & Ds. & Dukuhseti & Banjir bandang & rumah & 400 & $0,6-1$ & 1 hari \\
\hline & & $19-1-2014$ & Kec. & Dukuhseti & curah hujan muria tinggi & & & & \\
\hline & & 05.00 wib & Kab. & Pati & TPI Sekolah dan prasarana lain terendam & & & & \\
\hline
\end{tabular}




\begin{tabular}{|c|c|c|c|c|c|c|c|c|c|c|}
\hline No. & Nama Sungai & $\begin{array}{c}\text { HARI/TANGGAL } \\
\text { /JAM }\end{array}$ & Lokasi & $\begin{array}{l}\text { Sebab / Akibat / } \\
\text { Kejadian }\end{array}$ & Daerah Genangan & $\begin{array}{l}\text { Luas / } \\
\text { Pjg } \\
\text { Genangan }\end{array}$ & $\begin{array}{l}\text { Tinggi } \\
\text { (m) } \\
\text { Genangan }\end{array}$ & $\begin{array}{l}\text { Lama } \\
\text { (jam) }\end{array}$ & & No. \\
\hline 1 & 2 & 3 & 4 & 5 & 6 & 7 & 8 & 9 & & 1 \\
\hline \multirow[t]{3}{*}{8} & Sungai Poceho & Minggu & Ds. & Mejobo & Tanggul kiri drain poceho jebol & & & & & \\
\hline & & $19-1-2014$ & Kec. & Mejobo & $\mathrm{p}=15 \mathrm{~m}$, curah hujan tinggi & jalan & $1 \mathrm{~km}$ & $0,5-1 \mathrm{~m}$ & & 3 hari \\
\hline & & 05.00 wib & Kab. & Kudus & jalan raya mejobo tergenang & & & & & \\
\hline \multirow[t]{3}{*}{9} & Sungai Dawe & Minggu & Ds. & Golantepus & tanggul kiri jebol (utara balai desa Golantpus) & rumah & 50 & 0,5 & & 1 hari \\
\hline & & $19-1-2014$ & Kec. & Mejobo & $\mathrm{p}=2 \mathrm{~m}, \mathrm{t}=1 \mathrm{~m}$ & jalan & $100 \mathrm{~m}$ & 0,3 & & \\
\hline & & 03.00 wib & Kab. & Kudus & & & & & & \\
\hline \multirow[t]{3}{*}{10} & sungai Muneng & Senin & Ds. & Setrokalangan & luapan sungai muneng & sawah & $200 \mathrm{Ha}$ & $0,5-1$ & & 1 hari \\
\hline & & 20-Jan-14 & Kec. & Kaliwungu & & & & & & \\
\hline & & $06.00 \mathrm{wib}$ & Kab. & Kudus & & & & & & \\
\hline \multirow[t]{3}{*}{11} & Sungai Gelis & Senin & Ds. & Jurang & 1 orang meninggal dunia & & & & & \\
\hline & & 20-Jan-14 & Kec. & Gebog & terseret arus sungai gelis & & & & & \\
\hline & & 06.00 wib & Kab. & Kudus & & & & & & \\
\hline \multirow[t]{3}{*}{12} & Alasdowo & Senin & Ds. & Alasdowo & meluap curah hujan tinggi & rumah & 150 & & 1 & 3 hari \\
\hline & (anak sungai & 20-Jan-14 & Kec. & Dukuhseti & & sawah & $35 \mathrm{Ha}$ & & & \\
\hline & Pasokan) & 07.00 wib & Kab. & Pati & & tambak & $30 \mathrm{Ha}$ & & & \\
\hline \multirow[t]{3}{*}{13} & SWD. 2 & Senin & Ds. & Gerdu & Limpasan bendung karet SWD.2 & rumah & 150 & & 1 & 2 hari \\
\hline & & 20-Jan-14 & Kec. & Pecangaan & & sawah & $40 \mathrm{Ha}$ & & & \\
\hline & & 07.00 wib & Kab. & Jepara & & & & & & \\
\hline \multirow[t]{3}{*}{14} & SWD.2 & Senin & Ds. & Welahan & Limpasan Sal Pembuang Patoksewu & & & & & \\
\hline & & 20-Jan-14 & Kec. & Welahan & tanggul kiri kritis/bocor $p=10 \mathrm{~m}$ & sawah & $200 \mathrm{Ha}$ & & & 3 hari \\
\hline & & $10.00 \mathrm{wib}$ & Kab. & Jepara & limpas setinggi $20 \mathrm{~cm}$ & & & & & \\
\hline \multirow[t]{3}{*}{15} & SWD.2 & Senin & Ds. & Ketilengsingolelo & Tanggul Kanan jebol & rumah & 500 & $0.7-1$ & & \\
\hline & & 20-Jan-14 & Kec. & Welahan & $\mathrm{P}=10 \mathrm{~m}, \mathrm{t}=3 \mathrm{~m}$. & sawah & $460 \mathrm{Ha}$ & & & \\
\hline & & 10.00 wib & Kab. & Jepara & & & & & & \\
\hline
\end{tabular}




\begin{tabular}{|c|c|c|c|c|}
\hline No. & Nama Sungai & $\begin{array}{c}\text { HARI/TANGGAL } \\
\text { /JAM }\end{array}$ & Lokasi & $\begin{array}{c}\text { Sebab / Akibat / } \\
\text { Kejadian }\end{array}$ \\
\hline 1 & 2 & 3 & 4 & 5 \\
\hline \multirow[t]{3}{*}{16} & S. Purwogondo & Senin & Ds. & Batukali \\
\hline & & 20-Jan-14 & Kec. & Kalinyamatan \\
\hline & & 10.00 wib & Kab. & Jepara \\
\hline \multirow[t]{3}{*}{17} & JU.2 & Senin & Ds. & Kasian \\
\hline & & 20-Jan-14 & Kec. & Sukolilo \\
\hline & & 03.00 wib & Kab. & Pati \\
\hline \multirow[t]{3}{*}{18} & JU.1 \& JU.2 & Senin & Ds. & Poncomulyo \\
\hline & & 20-Jan-14 & Kec. & Sukolilo \\
\hline & & 03.00 wib & Kab. & Pati \\
\hline \multirow[t]{3}{*}{19} & $\begin{array}{l}\text { Drai Jati } \\
\text { Pasehan }\end{array}$ & Senin & Ds. & Bulungcangkring \\
\hline & & 20-Jan-14 & Kec. & Jekulo \\
\hline & Sungai & 03.00 wib & Kab. & Pati \\
\hline \multirow[t]{3}{*}{20} & Jogotuwo & Senin & Ds. & Kedungdowo \\
\hline & & 20-Jan-14 & Kec. & Kaliwungu \\
\hline & & 17.30 wib & Kab. & Kudus \\
\hline \multirow[t]{3}{*}{21} & Sungai Piji & Senin & Ds. & Tenggeles \\
\hline & & 20-Jan-14 & Kec. & Mejobo \\
\hline & & 18.00 wib & Kab. & Kudus \\
\hline \multirow[t]{3}{*}{22} & Kali Kencing & Senin & Ds. & Jati Wetan \\
\hline & & 20-Jan-14 & Kec. & Jati \\
\hline & & 10.00 wib & Kab. & Kudus \\
\hline
\end{tabular}

Daerah Genangan

6

curah hujan tinggi \& luapan s.purwogondo

Swah padi umur 30 hari

200 KK mengungsi

luapan sungai JU.2

persawahan tergenang

padi umur 50 hari, tebu umur 100 hari

Luapan JU.1 \& JU.2

sawah tergenang Padi umur 20 hari,

tebu umur 100 hari

luapan drain Jati Pasehan

swah tergenang padi umur 100 Hari

1 orang meninggal hanyut tebawa arus sungai

dikarenakan main di sungai serta penyakit ayan

di Dk. Badong Tenggeles,

tanggul kiri Sungai Piji jebol p=10 m, t= $1 \mathrm{~m}$

4 dukuh tergenang (barisan,gendok,kaligae,

Tanggulangin) curah hujan tingg

kali kencing tdk dpt menampung air \& meluap

Terminal kudus \& terminal kargo lumpuh total

akses pantura putus total

\begin{tabular}{|c|c|c|c|c|}
\hline $\begin{array}{l}\text { Luas / } \\
\text { Pjg } \\
\text { Genangan }\end{array}$ & $\begin{array}{l}\text { Tinggi } \\
\text { (m) } \\
\text { Genangan }\end{array}$ & $\begin{array}{l}\text { Lama } \\
\text { (jam) }\end{array}$ & & No. \\
\hline 7 & 8 & 9 & & 1 \\
\hline rumah & 200 & & 1 & 3 hari \\
\hline sawah & $200 \mathrm{Ha}$ & & & \\
\hline rumah & 15 & $0,6-1$ & & 5 hari \\
\hline sawah & $600 \mathrm{Ha}$ & $0,6-1$ & & 5 hari \\
\hline sawah & $400 \mathrm{Ha}$ & $0,6-1$ & & 5 hari \\
\hline rumah & 200 & $0,6-1$ & & 2 hari \\
\hline Jln & $200 \mathrm{~m}$ & 0,1 & & \\
\hline sawah & $150 \mathrm{Ha}$ & & & \\
\hline rumah & $150 \mathrm{kk}$ & & & \\
\hline rumah & $450 \mathrm{kk}$ & $1-1,5$ & & 7 hari \\
\hline sawah & $200 \mathrm{Ha}$ & & & \\
\hline jln & $1 \mathrm{~km}$ & & 1 & 7 hari \\
\hline
\end{tabular}




\begin{tabular}{|c|c|c|c|c|c|c|c|c|c|c|}
\hline No. & Nama Sungai & $\begin{array}{c}\text { HARI/TANGGAL } \\
\text { /JAM }\end{array}$ & Lokasi & $\begin{array}{c}\text { Sebab / Akibat / } \\
\text { Kejadian }\end{array}$ & Daerah Genangan & $\begin{array}{l}\text { Luas / } \\
\text { Pjg } \\
\text { Genangan }\end{array}$ & $\begin{array}{l}\text { Tinggi } \\
\text { (m) } \\
\text { Genangan }\end{array}$ & $\begin{array}{l}\text { Lama } \\
\text { (jam) }\end{array}$ & & No. \\
\hline 1 & 2 & 3 & 4 & 5 & 6 & 7 & 8 & 9 & & 1 \\
\hline \multirow[t]{11}{*}{23} & Kali Kencing & Selasa & Ds. & Jati Kulon & Dk. Kencing tergenang, Curah Hujan tinggi & rumah & $100 \mathrm{kk}$ & & 1 & 7 hari \\
\hline & & 21-Jan-14 & Kec. & Jati & kali kencing tdk dpt menampung air \& meluap & & & & & \\
\hline & & 05.00 wib & Kab. & Kudus & di tambah limpasan tanggul kiri Sungai Gelis & & & & & \\
\hline & & & & & mengancam prasarana industri pabrik PURA & & & & & \\
\hline & & & & & dan PLN/listrik & & & & & \\
\hline & & Selasa & Ds. & Tanjung karang & Curah Hujan tinggi & rumah & $200 \mathrm{kk}$ & & 1 & 7 hari \\
\hline & & 21-Jan-14 & Kec. & Jati & jln pantura \& jln Kds. Porwodadi lumpuh & jln & $200 \mathrm{~m}$ & $0,5-1$ & & \\
\hline & & 05.00 wib & Kab. & Kudus & & & & & & \\
\hline & & Selasa & Ds. & Jetis Kapuan & Curah Hujan tinggi & rumah & $500 \mathrm{kk}$ & $0,5-1$ & & 7 hari \\
\hline & & 21-Jan-14 & Kec. & Jati & 1 desa tergenang & & & & & \\
\hline & & 05.00 wib & Kab. & Kudus & & & & & & \\
\hline \multirow[t]{3}{*}{24} & SDW.2 & Selasa & Ds. & Blimbing Kidul & Tanggul Kiri jebol di 2 titik & rumah & 300 & $0.5-1$ & & 5 hari \\
\hline & & 21-Jan-14 & Kec. & Kaliwungu & Panjang $=15 \mathrm{~m}$, tinggi $=2 \mathrm{~m}$ & sawah & $300 \mathrm{Ha}$ & & & \\
\hline & & 05.00 wib & Kab. & Kudus & & & & & & \\
\hline \multirow[t]{3}{*}{25} & Sungai Dawe & Selasa & Ds. & Ngembal rejo & luapan sungai dawe $\&$ curah hujan tinggi & rumah & 50 & & 1 & 1 hari \\
\hline & & 21-Jan-14 & Kec. & Bae & & jalan & $150 \mathrm{~m}$ & 0,5 & & \\
\hline & & 05.00 wib & Kab. & Kudus & & & & & & \\
\hline \multirow[t]{3}{*}{26} & $\begin{array}{l}\text { Sungai } \\
\text { Tumpang }\end{array}$ & Selasa & Ds. & Megawon & Luapan Sungai Tumpang di gorong2 jln lingkar & rumah & 60 & $0,5-1$ & & $\begin{array}{l}12 \\
\text { Jam }\end{array}$ \\
\hline & & 21-Jan-14 & Kec. & Jati & Ngembal & & & & & \\
\hline & & 20.00 wib & Kab. & Kudus & & & & & & \\
\hline \multirow[t]{3}{*}{27} & $\mathrm{JU}$ & Kamis & Ds. & Pekuwon & Limpasan JU \& curah hujan tinggi & rumah & 300 & & 1 & 7 hari \\
\hline & & 23-Jan-14 & Kec. & Juwana & & sawah & $20 \mathrm{Ha}$ & & 1 & \\
\hline & & 20.00 wib & Kab. & Pati & & & & & & \\
\hline
\end{tabular}


Jurnal SIMETRIS, Vol 6 No 1 April 2015

ISSN: 2252-4983

\begin{tabular}{|c|c|c|c|c|c|c|c|c|c|c|}
\hline No. & Nama Sungai & $\begin{array}{c}\text { HARI/TANGGAL } \\
\text { /JAM }\end{array}$ & Lokasi & $\begin{array}{l}\text { Sebab / Akibat / } \\
\text { Kejadian }\end{array}$ & Daerah Genangan & $\begin{array}{l}\text { Luas / } \\
\text { Pjg } \\
\text { Genangan }\end{array}$ & $\begin{array}{l}\text { Tinggi } \\
\text { (m) } \\
\text { Genangan }\end{array}$ & $\begin{array}{l}\text { Lama } \\
\text { (jam) }\end{array}$ & & No. \\
\hline 1 & 2 & 3 & 4 & 5 & 6 & 7 & 8 & 9 & & 1 \\
\hline \multirow[t]{3}{*}{28} & $\mathrm{JU}$ & Kamis & Ds. & Bungasrejo & Limpasan JU \& curah hujan tinggi & rumah & 300 & & 1 & 7 hari \\
\hline & & 23-Jan-14 & Kec. & Juwana & & sawah & $108 \mathrm{Ha}$ & & 1 & \\
\hline & & 20.00 wib & Kab. & Pati & & & & & & \\
\hline \multirow[t]{3}{*}{29} & $\mathrm{JU}$ & Kamis & Ds. & Sejomulyo & Limpasan JU \& curah hujan tinggi & rumah & 200 & & 1 & 7 hari \\
\hline & & 23-Jan-14 & Kec. & Juwana & & sawah & $60 \mathrm{Ha}$ & & 1 & \\
\hline & & $20.00 \mathrm{wib}$ & Kab. & Pati & & & & & & \\
\hline \multirow[t]{3}{*}{30} & $\mathrm{JU}$ & Kamis & Ds. & Karangrejo & Limpasan JU \& curah hujan tinggi & rumah & 50 & 0,5 & & 7 hari \\
\hline & & 23-Jan-14 & Kec. & Juwana & & sawah & $20 \mathrm{Ha}$. & 0,5 & & \\
\hline & & 20.00 wib & Kab. & Pati & & & & & & \\
\hline \multirow[t]{5}{*}{31} & Bakalan & Kamis & Ds. & Kalipucang Wetan & Tanggul kanan jebol $\mathrm{p}=6 \mathrm{~m}$ & rumah & & 1,5 & & \\
\hline & & 23-Jan-14 & Kec. & Welahan & tanggul kiri jebol $p=20 \mathrm{~m}$ & & & & & \\
\hline & & 04.000 wib & Kab. & Japara & sudah 2 hari, jebolan semakin melebar & & & & & \\
\hline & & & & & 4 desa tergenang : Ds. Ketileng singolelo & & & & & \\
\hline & & & & & Ds. Paren, Ds. Kalipucang wtn, Ds. Welahan & & & & & \\
\hline \multirow[t]{3}{*}{32} & Sungai Dawe & Kamis & Ds. & Mejobo & parapet tanggul kiri sungai Dawe jebol & & & & & \\
\hline & & 23-Jan-14 & Kec. & Mejobo Kudus & $\mathrm{t}=1,2 \mathrm{~m}$, lebar $=3 \mathrm{~m}$ & & & & & \\
\hline & & 10.00 wib & Kab. & Japara & & & & & & \\
\hline \multirow[t]{6}{*}{33} & Sungai Wulan & Kamis & Ds. & Undaan Lor & Tanggul sleding & & & & & \\
\hline & & 23-Jan-14 & Kec. & Undaan & $\mathrm{p}=15 \mathrm{~m} \mathrm{t}=6 \mathrm{~m} \mathrm{l}=3,5 \mathrm{~m}$ & & & & & \\
\hline & & 10.00 wib & Kab. & Japara & tanggul yang masih utuh $2,5 \mathrm{~m}$ & & & & & \\
\hline & & & & & mengancam wilayah kec. Undaan kudus & & & & & \\
\hline & & & & & $\operatorname{tgl} 21-01-2014$ sudah ditangani dg alat berat & & & & & \\
\hline & & & & & sleding lagi & & & & & \\
\hline
\end{tabular}


$34 \quad \begin{aligned} & \text { Luapan } \\ & \text { sungai Afur }\end{aligned}$

C.71

Kamis
23-Jan-14
13.31 wib

Ds.

Kec.

Kab.
- Dk. Norowito Ds. Ketanjung Kec. Karanganyar

$$
\text { rumah }=300
$$

- Dk. Kedungbanteng Ds. Wonorejo karanganyar

rumah $=1200$, sawah $=169 \mathrm{Ha}$.

\begin{tabular}{|c|c|c|c|c|}
\hline No. & Nama Sungai & $\begin{array}{c}\text { HARI/TANGGAL } \\
\text { /JAM }\end{array}$ & Lokasi & $\begin{array}{r}\text { Sebab / A } \\
\text { Kejad }\end{array}$ \\
\hline 1 & 2 & 3 & 4 & \\
\hline \multirow[t]{3}{*}{35} & Sungai Lusi & Sabtu & Ds. & Karangsari \\
\hline & & 25-Jan-14 & Kec. & Jrati \\
\hline & & 06.00 wib & Kab. & Grobogan \\
\hline \multirow[t]{3}{*}{36} & JU.2 & Selasa & Ds. & Wegil \\
\hline & & 28-Jan-14 & Kec. & Sukolilo \\
\hline & & 04.00 wib & Kab. & Pati \\
\hline \multirow[t]{3}{*}{37} & Sungai Londo & Selasa & Ds. & Wonosoco \\
\hline & & 28-Jan-14 & Kec. & Undaan \\
\hline & & 03.00 wib & Kab. & Kudus \\
\hline \multirow[t]{3}{*}{38} & Sungai Piji & Selasa & Ds. & Tenggeles \\
\hline & & 28-Jan-14 & Kec. & Mejobo \\
\hline & & 03.00 wib & Kab. & Kudus \\
\hline \multirow[t]{3}{*}{39} & Sungai Piji & Selasa & Ds. & Kesambi \\
\hline & & 28-Jan-14 & Kec. & Mejobo \\
\hline & & $12.00 \mathrm{wib}$ & Kab. & Kudus \\
\hline
\end{tabular}

\section{Daerah Genangan}$$
6
$$

$\begin{array}{llrr}\begin{array}{l}\text { Luas / } \\ \text { Pjg } \\ \text { Genangan }\end{array} & \begin{array}{l}\text { Tinggi } \\ (\mathbf{m})\end{array} & \begin{array}{l}\text { Lama } \\ \text { Genangan }\end{array} & \text { No. } \\ \quad 7 & 8 & 9 & 1\end{array}$

- Dk Tugu Ds. Ngemplik Kec. Karanganyar rumah $=700$, sawah $=60 \mathrm{Ha}$.

- Ds. Cangkringrembang kec. Karanganyar rumah $=200$, sawah $100 \mathrm{Ha}$

Luapan Sungai Lusi

banjir bandang dan Luapan Sungai JU.2

Hujan di Peg. Kapur Utara mengakibatkan

banjir bandang, 46 rumah rusak

Curah Hujan lereng Muria tinggi

Tanggul kanan sungai Piji jebol. $\mathrm{P}=25 \mathrm{~m}$.

Curah hujan lereng Muria tinggi

terjadi Banjir bandang,

Tanggul Kanan Sungi Piji Jebol, P= $20 \mathrm{~m}$ rumah

jalan

sawah

sawah

$200 \mathrm{Ha}$

$30 \quad 0.3 \mathrm{~m}$

$0.3 \mathrm{~m}$

0.6-0.7 m rumah

pemukiman

3 RT

tergenang
$300 \quad 0,6 \mathrm{~m}$

$0.7 \mathrm{~m}$ 
Jurnal SIMETRIS, Vol 6 No 1 April 2015

ISSN: 2252-4983

\begin{tabular}{|c|c|c|c|c|c|c|c|c|c|}
\hline \multirow[t]{3}{*}{40} & \multirow[t]{3}{*}{ Sungai Logung } & Selasa & Ds. & Sadang & \multicolumn{5}{|l|}{ Curah hujan lereng Muria tinggi } \\
\hline & & 28-Jan-14 & Kec. & Jekulo & \multicolumn{5}{|l|}{ Tanggul Kanan Sungi Logung Jebol, } \\
\hline & & $12.00 \mathrm{wib}$ & Kab. & Kudus & \multicolumn{5}{|l|}{$\mathrm{P}=3 \mathrm{~m}, \mathrm{t}=2 \mathrm{~m}$} \\
\hline 41 & Sungai Gelis & Selasa & Ds. & Jati Kulon & \multicolumn{5}{|l|}{ Banjir Bandang, 9 rumah rusak berat } \\
\hline & & 28-Jan-14 & Kec. & Jati & \multicolumn{5}{|l|}{ Mengancam pemukiman di sepanjang } \\
\hline No. & Nama Sungai & $\begin{array}{l}\text { HARI/TANGGAL } \\
\text { /JAM }\end{array}$ & Lokasi & $\begin{array}{l}\text { Sebab / Akibat / } \\
\text { Kejadian }\end{array}$ & Daerah Genangan & $\begin{array}{l}\text { Luas / } \\
\text { Pjg } \\
\text { Genangan }\end{array}$ & $\begin{array}{l}\text { Tinggi } \\
\text { (m) } \\
\text { Genangan }\end{array}$ & $\begin{array}{l}\text { Lama } \\
\text { (jam) }\end{array}$ & No. \\
\hline \multirow[t]{2}{*}{1} & 2 & 3 & 4 & 5 & 6 & 7 & 8 & 9 & 1 \\
\hline & & 12.00 wib & Kab. & Kudus & \multicolumn{5}{|l|}{ bantaran Sungai Gelis } \\
\hline \multirow[t]{3}{*}{42} & Sungai Mayong & Selasa & Ds. & Mayong & \multirow[t]{3}{*}{ Luapan Sungai Mayong } & rumah & 30 & $0.6 \mathrm{~m}$ & \multirow[t]{3}{*}{2 Hari } \\
\hline & & 28-Jan-14 & Kec. & Mayong & & jalan & $300 \mathrm{~m}$ & & \\
\hline & & 14.00 wib & Kab. & Jepara & & sawah padi & $60 \mathrm{Ha}$. & & \\
\hline \multirow[t]{3}{*}{43} & S. Pecangaan & Selasa & Ds. & Karang Randu & \multirow{3}{*}{$\begin{array}{l}\text { Tanggul kiri Sungai Pecangaan Jebol } \\
P=15 \mathrm{~m}, \mathrm{t}=2 \mathrm{~m} \text {. }\end{array}$} & rumah & 30 & $0,7 \mathrm{~m}$ & \multirow[t]{3}{*}{5 hari } \\
\hline & & 28-Jan-14 & Kec. & Pecangaan & & Jalan desa & & $1 \mathrm{~m}$ & \\
\hline & & 14.00 wib & Kab. & Jepara & & sawah padi & $120 \mathrm{Ha}$. & & \\
\hline
\end{tabular}




\section{PERANCANGAN DIAGRAM ARSITEKTUR SPK}

Pada rancangan arsitektur SPK bakat minat yang dibangun terdapat data internal, dan data ekternal yang diekstrasi ke dalam database dan model base seperti yang ditunjukan pada Gambar 2.

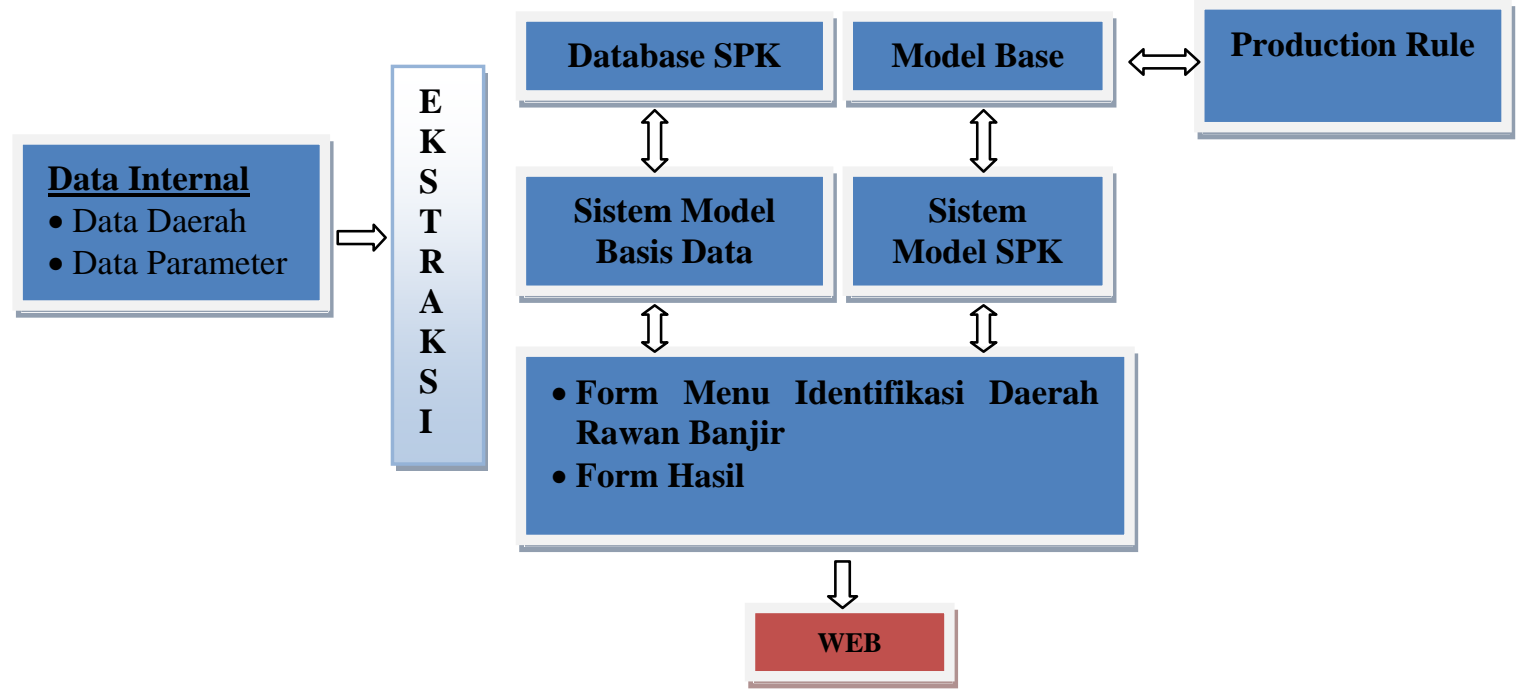

Gambar 2. Arsitektur Sistem Identifikasi Rawan Banjir

\section{PERANCANGAN SISTEM}

\subsection{Decission Tree}

Pohon keputusan yang dibangun ditunjukan pada Gambar 3. Dimana terdapat ciri umum yang diambil dibedakan atas dua yaitu, sudah pernah banjir dan langganan banjir. Sementara terdaoat enam parameter daerah rawan banjir seperti yang ditunjukan pada Gambar 3.

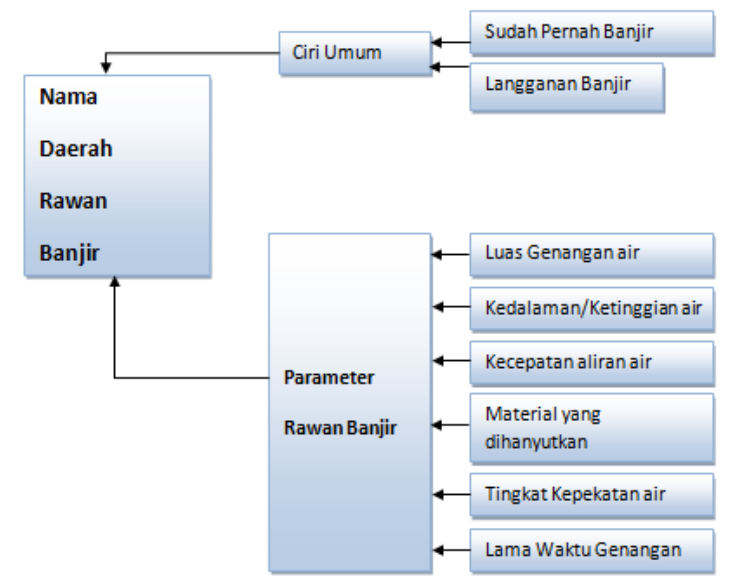

Gambar 3. Decission Tree Parametrer Rawan Banjir

\subsection{Rule Identifikasi Daerah Rawan Banjir} berikut.

Rule yang dibangun menggunakan metode production rule. Ditulis dalam pseudocode sebagai

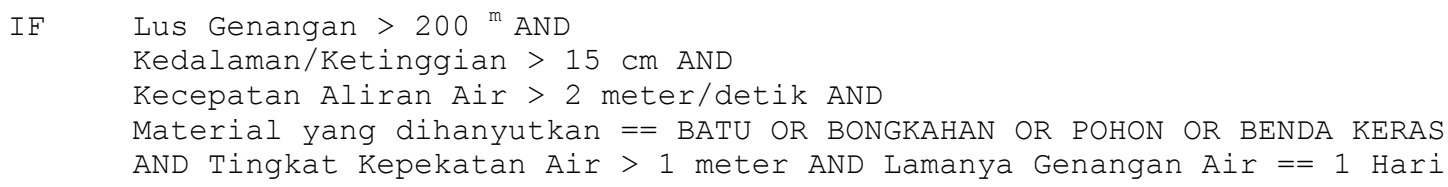


THEN

RAWAN BANJIR

Model rule based yang dibangun untuk identifikasi daerah rawan banjir dengan enam parameter, antara lain luas genangan, kedalaman/ketinggian, kecepatan aliran air, material yang dihanyutkan, tingkat kepekatan air, dan lamanya genangan air.

\section{KESIMPULAN}

1) Berdasarkan analisa terhadap peta banjir di Kudus, dapat disimpulkan bahwa daerah kudus masih dikategorikan sebagai daerah rawan banjir dengan persebaran yang cukup tinggi.

2) Telah dirumuskan sebuah rule berdasarkan enam parameter diantaranya luas genangan, kedalaman/ketinggian air, kecepatan aliran air, material yang dihanyutkan, tingkat kepekatan air, lamanya genangan air.

\section{DAFTAR PUSTAKA}

[1] Turban, E., and Aronson, J.E., 2005, Decission Support System and Intelligent System, 6th Edition, Prentice Hall, Inc., New Jersey

[2] Zubaidah,dkk., 2005, Analisa daerah potensi banjir Di pulau sumatera, jawa dan kalimantan menggunakan citra avhrr/noaa-16, Pertemuan Ilmiah Tahunan MAPIN XIV, ITS, Surabaya

[3] Indrianawaty, 2009, Penyusunan Basis Data Untuk Identifikasi Daerah Rawan Banjir Dikaitkan Dengan Infrastruktur Data Spasial (Studi Kasus Propinsi Jawa Barat), Skripsi, Program Studi Teknik Geodesi, ITB.

[4] Mislan, 2011, Bencana Banjir, Pengenalan Karakteristik Dan Kebijakan Penanggulangannya Di Provinsi Kalimantan Timur, Jurnal Mulawarman Scientifie, volume 10 nomor 1, ISSN 1412-498X. 